\title{
TIPOLOGI TATA RUANG RUMAH BANGSAWAN DI DALAM BALUWARTI KRATON YOGYAKARTA, BERDASARKAN GELAR KEBANGSAWANAN
}

Istiana Adianti, Program Studi Arsitektur Fakultas Teknik Universitas Widya Mataram Yogyakarta, tinaadianti@gmail.com

\begin{abstract}
Abstrak :
Rumah hunian bangsawan di kraton Yogyakarta disebut dalem, yang dikategorikan dalam bangunan rumah joglo. Dalem diberikan kepada keturunan raja dan orang yang telah berjasa kepada kraton untuk memberikan keleluasaan dalam mengatur ruamhnya sendiri sekaligus sebagai bentuk pelestarian budaya. Sebagai keturunan raja dan orang yang telah berjasa atau disebut bangsawan memiliki nama dan gelar kebangsawanan sesuai aturan dilingkungan kraton Yogyakarta. Pengelompokan dalem menurut kepemilikan awal dalem berdasarkan nama dan gelar didalam baluwarti Kraton, didapatkan tatanan kecenderuangan tatanan ruang rumah tinggalnya. Walaupun pada dasarnya dikategorikan dalam rumah tradisonal Yogyakarta tipe Joglo. Dimana Joglo memiliki hirarki kelengkapan paling tinggi dibanding tipe yang lain dalam hal susunan ruangnya. Pada kelompok tertentu terdapat peruabahan perubahan yang tidak sesuai dengan karakter rumah joglo. Perubahan tersebut terjadi pada kelompok yang memiliki ketrikatan paling jauh dengan kraton.
\end{abstract}

Kata Kunci : Ruang, Dalem, Gelar, Kebangsawanan.

\section{LATAR BELAKANG}

Yogyakarta tidak lepas dari Kraton sebagai pusat pemerintahan pada awalnya. Tatanan Kraton sebagai pusat pemerintahan kerajaan Jawa memiliki ciri 4 elemen yaitu; Kraton sebagai Pusatnya, Alun alun, Masjid dan Pasar. Posisi ke empat elemen tersebut membentuk poros atau axsis Utara-Selatan. Komplek Kraton dikelilingi pagar yang disebut Baluwerti, didalam baluwarti terdapat rumah abdi dalem, rumah bangsawan dan inti Kraton dimana raja tinggal dimana diekelilingi pagar tinggi yang disebut cepuri. Menurut Kamus Besar Bahasa Indonesia (KBBI) yang disebut bangasawan adalah keturunan orang mulia (terutama raja dan kerabatnya). Budaya Jawa mengenal gelar kebangsawanan untuk semakin menegaskan status bangsawannya, gelar tersebut diberikan kepada masyarakat kraton ataupun diluar kraton yang dianggap berjasa kepada keraton. Para bangsawan tersebut bertempat tinggal disekitar cepuri Karton sebagai cara untuk melindungi istana selain juga berfungsi untuk mempertahankan budaya. Tempat tinggal bangsawan tersebut merupakan wujud kebijagsanaan raja yang diberikan kepada pangeran untuk mengelola rumah tinggalnya sendiri. Sebutan rumah tinggal diistilahkan sebagai dalem.

Menurut Kartono,2005 Rumah Tinggal bagi orang Jawa adalah tempat atau tatanan tempat yang terlihat dalam bagian-bagian rumah tinggal. Istilah dalem yang ditemui dalam Omah dapat diartikan sebagai ke-aku-an orang Jawa, karena dalam bahasa jawa halus kata dalem menjadi padanan kata aku. Tatanan ruang rumah jawa memuat 3 bagian linear yaitu pendopo (bagian depan), pringgitan (bagian tengah) dan dalem (bagian belakang). Tiga bagian linear tersebut sangat terlihat jelas pada rumah Joglo dimana jika didiami oleh ningrat rumah joglo tersebut menjadi lebih lengkap dengan ditambahkan gandok pada belakang dan kanan kiri dalem.

Dalem diberikan oleh raja yang sedang berkuasa untuk putra atau putri baik dari permaisuri ataupun selir. Bahkan pada beberapa dalem, raja memberikan kepada orang yang dianggap 
berjasa kepada kraton. Jika pemilik pertama sudah meninggal, dalem bisa diberikan ke pada keturunannya atau diberiakan kepada kerabat yang lainnya sesuai dengan kebijagsanaan raja yang sedang berkuasa. Pada saat ini beberapa dalem sudah beralih fungsi tidak lagi menjadi hunian serta terjadi perubahan kepemilikan.

Penelitian difokuskan pada dalem yang terletak didalam baluwarti. Dengan bantuan literatur, wawancara dan dokumentasi, tata ruang yang akan dikaji adalah tata ruang asli dalem tersebut. Pada kenyataannya banyak terjadi perubahan bentuk dan tata ruang pada dalem yang ada akibat perubahan fungsi, dimana dalem yang sekarang tidak lagi menjadi rumah tinggal pada beberapa kasus. Tujuan dari penelitian ini adalah mengetahui tipologi ruang pada rumah bangsawan, walapun secara teori rumah tersebut dikategorikan dalam rumah joglo. Penelitian ini menggunakan metode penelitian kualitatif. Dimana data primer didapatkan dengan melakukan studi literatur dan pengamatan langsung dilapangan untuk mendapatkan sebaran dalem di dalam baluwarti Kraton Yogyakarta dan kemudian setelah sebaran ditemukan dilakukan wawancara dan pendokumentasian dalem tersebut. Awal pengelopokan berdasarkan gelar kebangsawanan kemudian masing masing dalem disetiap kelompok di gambar ulang serta sebaran/posisi didalam baluwarti. Setelah pengelompokan tersebutm, masing-masing dalem diidentifikasi berdasarkan kriteria rumah joglo. Berdasarkan identifikasi tersebut dapat ditemukan kecenderungan disetuap kelompok.

\section{STUDI PUSTAKA}

\section{a. Rumah /Tempat Tinggal di Jawa}

Rumah atau Omah memiliki arti yang erat bagi kehidupan orang jawa. Bagi orang jawa terdapat 3 perinsip hidup yaitu sandang (pakaian), pangan (makanan) dan papan (temapt tinggal). Rumah tinggal orang jawa dari bentuknya memiliki 4 tipe yaitu panggang pe, kampung, limasan dan joglo. Nama-nama tersebut merujuk dari jenis atap yang digunakan. Joglo merupakan tipe hunian yang paling besar dibanding ketiga lainnya. Ciri umum joglo adalah penggunaan blandar bersusun yang disebut blandar tumpangsari.

Susuan ruang rumah joglo dianggap paling ideal sebagai rumah tradisional jawa, karena tersusun secara jelas dan terbagi menjadi tiga bagian. Bagian tersebut adalah pendapa yang digunakan sebagai ruang pertemuan, pringsitan digunakan sebagai tempat pementasan wayang, dan omah jero sebagai ruang keluarga. Dalam omah jero terdapat 3 buah kamar (senthong) yaitu senthong tengah, senthong kanan, senthong kiri.

\section{b. Dalem}

Rumah

$$
\text { Joglo milik }
$$

bangsawan/ningrat/kerabat raja disebut dalem. Pada dalem terdapat penambahan ruang memanjang disisi kanan dan kiri omah jero yang disebut gandok. Gandok difungsikan sebagai rumah tinggal keluraga atau abdi dalem. Terdapat juga pembatas antara pendopo dengan pringgitan yang disebut longkangan, longkangan tersebut berfungsi sebagai jalan kereta. Kompleks dalem dikelilingi pagar (beteng) tinggi dan memiliki kisaran luas $1000 \mathrm{~m}^{2}-10.000 \mathrm{~m}^{2}$. Untuk masuk kedalam komplek dalem terdapat pintu gerbang (regol) yang diletakkan pada beteng depan pada sisi kanan bangunan atau di kedua sisinya. Posisi regol dengan jalan umum kadang memiliki jarak, jarak 
tersebut bervariasi tergantung posisi lahan dalem dengan jalan umum. Sehingga pemilik rumah membuat jalan pribadi untuk masuk ke regol dari jalan umum, jalan tersebut bernama gledegan.

Didalam kompleks dalem terdapat halaman depan berfungsi untuk menampung kegiatan publik sedangkan halaman belakang berfungsi untuk mewadahi kegiatan privat. Pemisah antara halaman depan dimana berdiri pendopo dengan halaman belakang dimana terdapat omah jero dan gandok, terdapat regol kecil yang disebut seketheng.

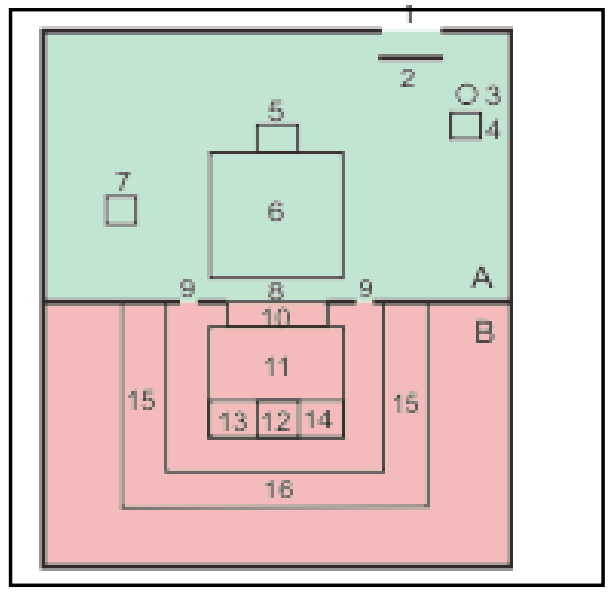

Gambar 1. Tata Ruang Dalem

Sumber: Wibowo, 1998

1.Regol, 2.Rana, 3.Sumur, 4.Langgar, 5.Kuncung, 6.Pendopo, 7. Kandang Kuda, 8.Longkangan, 9.Seketheng, 10.Pringgitan, 11.Dalem, 12.Senthong Tengah, 13.Senthong Kanan/Tengen, 14.Senthong Kiri/Kiwo, 15.Gandok, 16.Dapur, A.Halaman Depan, B.Halaman Beakang

\section{c. Orientasi Rumah Jawa}

Jika dilihat dari Gambar 1 Orientasi rumah di daerah Yogyakarta mengarah ke Selatan. Terlihat dari posisi Langgar berada di sisi kanan bangunan pendopo, yang bisa ditafsirkan kiblat arah barat berada disisi kanan pendopo.

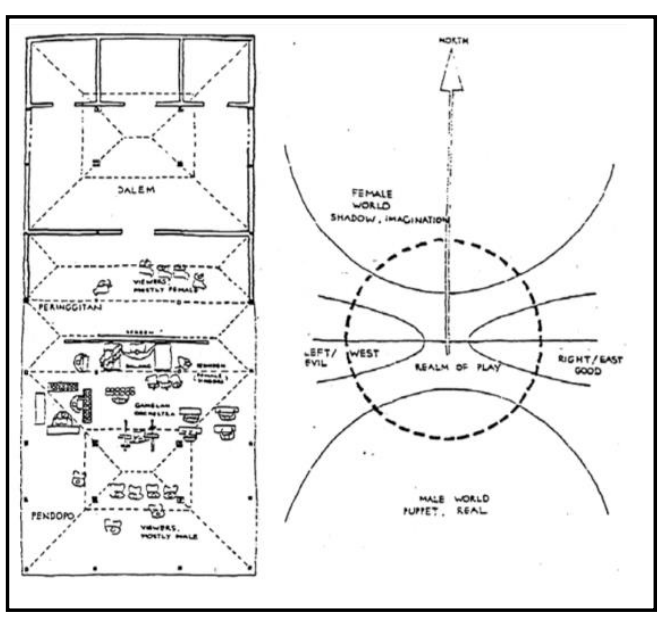

Gambar 2. Posisi Pageralaran Wayang Sumber : Katono, 2005

Selain itu adanya kepercayaan kepada Laut Selatan dimana diyakini Nyai Roro Kidul berada. Lay out pagelaran wayang yang diadakan di Pringgitan dan Pendopo, terlihat jelas bahwa orientasi bangunan menghadap ke selatan.

\section{d. Gelar Kebangsawanan}

Berdasarkan stratifikasi sosial masyarakat kraton dikelompokkan menjadi dua golongan, yaitu golongan bangsawan atau ningrat (mereka yang memiliki hubungan darah atau kekerabatan dengan raja atau sultan) serta golongan abdi dalem kraton atau priyayi (mereka yang mempunyai status sebagai pegawai kraton). Nama dan gelar di kraton Yogyakarta diberikan kepada keluarga sultan dan abdi dalem. Sisitem penamaan dan pemebrian gelar di kraton Yogyakarta sangat bervariasi dan terpola, sehingga dapat menunjukkan identitas sosial pemiliknya. 


\section{e. Tipologi Tata Ruang}

Tipologi adalah rangkaian proses analisis dengan mengkalisfikasikan obyek arsitektur menjadi beragam tipe bentuk. Tipe tersebut bisa diambil berdasarkan kesamaan suatu obyek (Setyabudi, 2012)

\section{ANALISA DAN PEMBAHASAN}

a. Sebaran Dalem di dalam Baluwarti Kraton Yogyakarta

Didalam baluwarti Kraton

Yogyakarta terdapat 13 dalem yang berhasil didata (Ikaputra, 1993). Dari 13 dalem tersebut 2 dalem tidak bisa di dokumentasi ulang. Ditambahkan dalem yang diperuntukkan untuk orang yang diangap penting oaleh raja sebanyak 2 dalem yang berhasil didokumentasi.

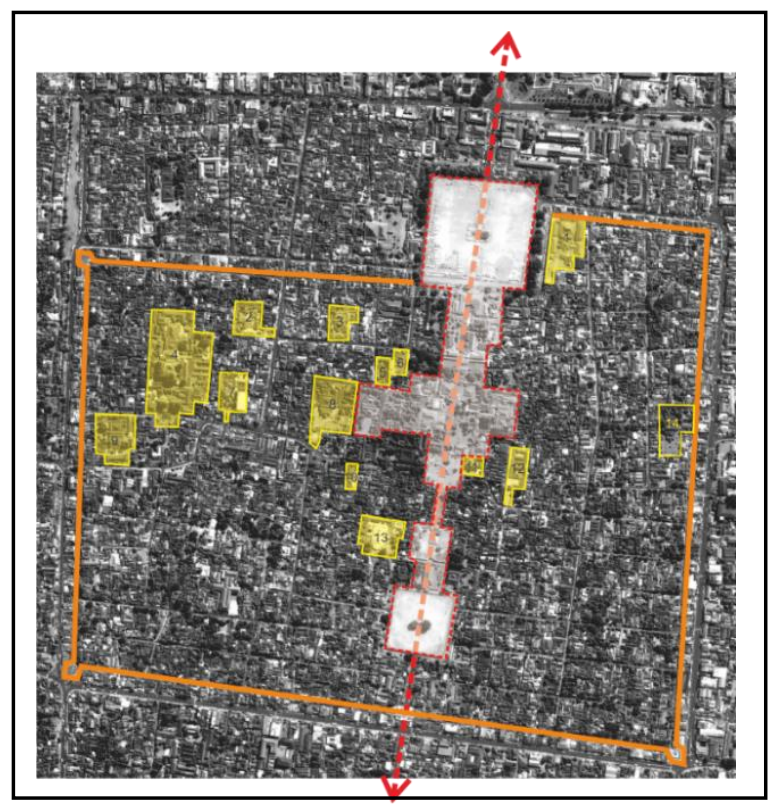

Gambar 3. Sebaran dalem di dalam

Baluwarti Kraton Yogyakarta

Sumber: Adianti, 2019

1.Dalem Condrokiranan, 2.Dalem Suryoputro baru, 3.Dalem Benawan, 4.Dalem Mangkubumen, 5.Dalem Purbonegaran, 6.Dalem Joyokusuman, 7.Dalem Purbayan, 8.Dalem Pakuningratan, 9.Dalem Kaneman, 10. Dalem Sastrosupartan,
11. Dalem Djoyokusuman, 12.Dalem Suryoputro baru, 13. Dalem Ngabean.

\section{b. Sejarah tiap Dalem}

1. Dalem Condrokiranan

Memiliki luas $8.325 \mathrm{~m} 2$, sebelum beralih fungsi dalem ini ditempati oleh Kanjeng Ratu Condro Kirono istri dari KPH Danurejo VII(Patih). Setelah itu pendopo digunakan oleh Sastra dan Kebudayaan UGM dan ASTI (Akademi Seni Tari Indonesia). Saat ini dalem digunakan sebagai musem Sono Budoyo II.

2. Dalem Suryoputro baru

Didirikan oleh HB VII untuk putranya BRM Suryo Putro. Saat ini masih ditempati oleh keluarga BRM Suryo Putro bersamaan dengan digunaknnya sebagain kompleks dalem untuk sekolahan.

3. Dalem Benawan

Didirikan tahun 1930-an dihuni oleh Pangeran Suryo Negara (putra HB VIII), dam kemudian tahun 1964 digunakan oleh Pangeran Benowo (putra HB IX). Sampai saat ini masih ditempati oleh pewaris Pangeran Benowo.

4. Dalem Mangkubumen

Didirikan tahun 1865 yang kemudian ditempati oleh putra mahkota (Pangeran Adipati Anom). Setelah naik tahta, dalem ini digunakan oleh GPH Mangkubumi dan terakhir ditinggali oleh GPH Buminoto. Kemudian beralih fungsi menjadi sekolah sampai sekarang.

5. Dalem Purbonegaran

Dibangun tahun 1828 dan digunahakn sebagai hunian oleh BRM Purbonegoro. Saat ini masih digunakan sebagai rumah 
tinggal akan tetapi pendoponya digunakan sebagai butik.

6. Dalem Joyokusuman

Didirikan tahun 1916 dan ditempati oleh Wedono Condrokusumo (sepupu HB VII). Kemudian ditempati oleh GBPH Bintoro adik HB IX yang bertugas sebagai ajudan raja. Kemudian tahun 1988 ditempati oleh adik HB X yaitu GBPH Joyokusumo. Saat ini selain digunakan untuk ruamh tinggal juga digunakan sebgai restaurant dan toko souvenir

7. Dalem Purbayan

Dibangun berkisar tahun 1829 untuk diberikan kepada Pangeran Purbayan oleh HB VII. Terjadi perubahan fungsi sebagai asrama mahasiswa dan sekolah. Pada tahun 1980 dijual kepada Probosutedjo sampai sekarang.

8. Dalem Pakuningratan

Berdiri tahun 1877 pada masa HB VII untuk kediaman Pangeran Purboyo(putra mahkota) yang kemudian diangkat menjadi $\mathrm{HB}$ VIII. Saat ini masih ditinggali oleh kerbat Pangeran Purboyo, dan saat ini digunakan sebagai restaurant pada pendoponya.

9. Dalem Kaneman

1855 secara keseluruhan bangunan ini selsesai dibangun, dan ditempati pertama kali oleh KRT Suryadi (putra HB VII) kemudian berpindah waris ke KRT Suro Negoro. Penerus ketiga adalah KRT Wiroguno dan terakhir adalah GKR Anom Brata (putri HB IX)

10. Dalem Sastrosupartan

Dalem dengan luas $4000 \mathrm{~m}^{2}$, mulai ditempati tahun 1920, rumah ini diberikan oleh HB VII untuk Raden Panji Sastrosuprapto.
Tahun 1940 dalem ini dibeli oleh HB IX yang kemudian diberikan kepada mertuanya yaitu Raden Wedana Puwowinoto. Saat ini masih digunakan sebagai rumah tinggal.

11. Dalem Djoyokusuman

Pada awalnya ditempati oleh GPH Tedjokusumo (putra HB VII dengan Gusti Kanjeng Ratu Kencono) dan kemudian diberikan kepada GBPH Djojokusumo (putra HB VII dengan BRAy Retnomandoyo). Saat ini masih digunakan sebagai rumah tinggal putra $\mathrm{GBPH}$ Djojokusumo.

12. Dalem Suryoputro lama

Dibangun tahun 1877, dihuni oleh Putra HB VI kemudian ditempati oleh BPPH Hadikusumo. Saat ini digunakan untuk asrma polisi

13. Dalem Ngabean

Pada awalnya didimaimoleh Pangeran Ngadisuryo yang merupakan putra dari HB II, Pangeran Ngadisuryo juga dikenal sebagai Pangeran Ngabei. Kemdian berpindah tangan kepemilikannya ke Probosutedjo dan kemudian terakir menjadi milik Romo Tunggul Panutun. Saat ini dalem digunakan sebagai restaurant.

\section{c. Tata Ruang Dalem}

Tata ruang disetiap dalem di identifikasi berdasarkan areanya. Halaman depan dan ruang-ruang yang ada didalamnya dikategorikan sebagai zona publik, halaman belakang dan ruang-ruang yang ada didalamnya dikategorikan sebagai zona privat. Sehingga didapat pengelompokkan sebagai berikut: Tabel 1. Pengelompokkan ruang. 


\begin{tabular}{|c|c|c|}
\hline \multirow[t]{3}{*}{ Publik } & \multirow{3}{*}{$\begin{array}{l}\text { Halaman } \\
\text { Depan }\end{array}$} & Gledegan-Regol \\
\hline & & Mushola/Langgar \\
\hline & & $\begin{array}{l}\text { Kuncung-Pendopo- } \\
\text { Longkangan }\end{array}$ \\
\hline \multirow[t]{3}{*}{ Privat } & \multirow{3}{*}{$\begin{array}{l}\text { Halaman } \\
\text { Belakang }\end{array}$} & Pringgitan \\
\hline & & $\begin{array}{l}\text { Omah Jero/Dalem } \\
\text { Ageng }\end{array}$ \\
\hline & & Gandok \\
\hline
\end{tabular}

Sumber :Penulis, 2019

Berdasarkan 13 dalem yang berhasil didata ulang dan berada di dalam baluwarti, menurut sejarah berdirinya setiap dalem dapat dikelompokkan menjadi 3 kelompok. Kelompok 1, dalem yang digunakan oleh putra mahkota atau calon putra mahkota. Kelompok 2, dalem yang dihuni oleh pangeran, putra raja dari permaisuri maupun selir raja. Kelompok 3, dalem yang dihuni oleh seseorang yang dianggap penting oleh raja. Pengelompokkan ini berdasarkan hubungan dengan raja, yang dapat dilihat dari gelar disetiap penghuninya.

Tabel 2. Pengelompokan dalem

\begin{tabular}{|c|c|c|c|}
\hline Kel. & 1 & 2 & 3 \\
\hline Status & $\begin{array}{l}\text { Putra } \\
\text { Mahkota }\end{array}$ & Pangeran & Kerabat Raja \\
\hline \multirow[t]{4}{*}{ Gelar } & \multirow[t]{4}{*}{ GPH } & $\begin{array}{l}\text { BRM } \\
\text { (Bendoro } \\
\text { Raden Mas) }\end{array}$ & Wedono \\
\hline & & $\begin{array}{l}\text { GPH (Gusti } \\
\text { Pangeran } \\
\text { Haryo) }\end{array}$ & $\begin{array}{l}\text { KRT (Kanjeng } \\
\text { Raden } \\
\text { Tumenggung) }\end{array}$ \\
\hline & & Pangeran & $\begin{array}{l}\text { KPH (Kanjeng } \\
\text { Pangeran } \\
\text { Haryo) }\end{array}$ \\
\hline & & & Raden \\
\hline \multirow[t]{7}{*}{ Dalem } & Mangkubumen & $\begin{array}{l}\text { Suryoputro } \\
\text { lama }\end{array}$ & Condrokiranan \\
\hline & \multirow[t]{6}{*}{ Pakuningratan } & Benawan & Joyokusuman \\
\hline & & Purbonegaran & Kaneman \\
\hline & & Purbayan & \multirow[t]{4}{*}{ Sastrosupartan } \\
\hline & & Djoyokusuman & \\
\hline & & $\begin{array}{l}\text { Suryoputro } \\
\text { lama }\end{array}$ & \\
\hline & & Ngabean & \\
\hline
\end{tabular}

Sumber: Penulis, 2019
Kelompok 1

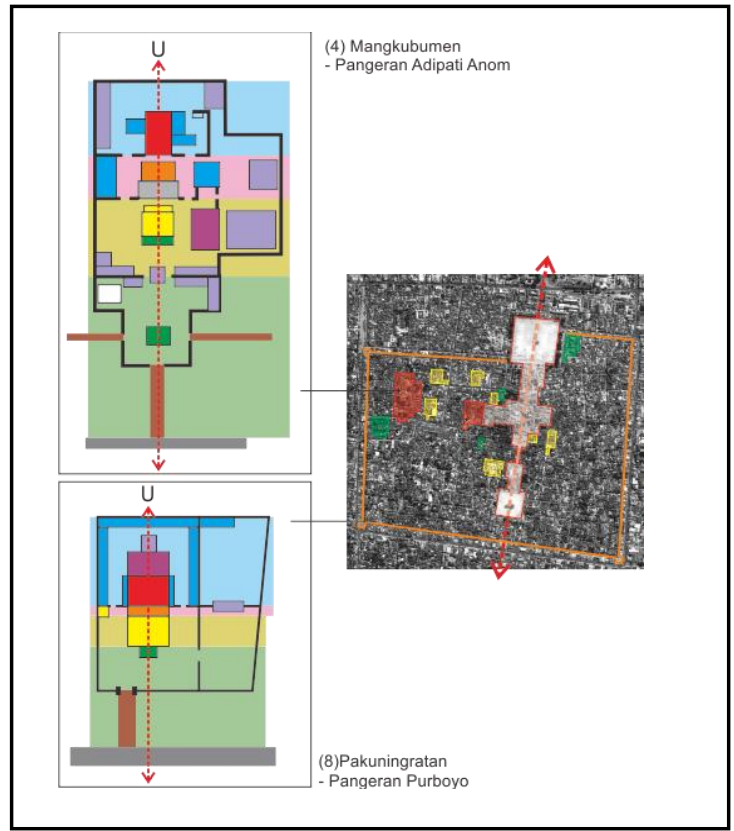

Gambar 4. Dalem kelompok 1

Sumber : Adianti, 2019

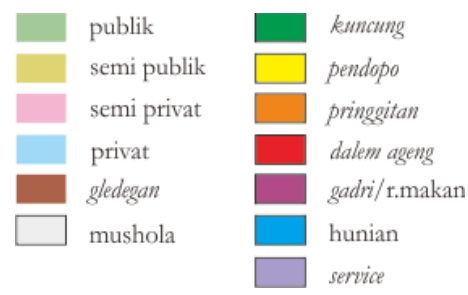

Dalem Mangkubumen dipersiapkan untuk tempat tinggal putra mahkota, sedangkan dalem Pakuningratan pernah ditinggali calon putra mahkota. Berdasarkan posisinya kedua dalem berada di barat Kraton dengan posisi hampir segaris dengan Kedhaton-pusat dari kompleks kraton dan menempati tapak yang terluas dibanding dalem yang lain. Orientasi bangunan kedua dalem tersebut kearah Selatan. Tata Ruang kedua dalem tersebut sesuai dengan perinsip dasar rumah joglo, rumah tradisonal jawa. Dalem Mangkubumen memiliki kompleksitas yang hampir mirip dengan kraton. Ruang service diletakkan menyebar sesuai dengan fungsi dan mendukung kegaiatan 
sesuai zonanya. Misalnya Kandang Keretha diletakkan di zona publik karena kegiatan yang diwadahi berada disekitar pendopo. Dapur diletakkan di zona privat karena kegiatannya untuk menyiapkan makanan bagi pemilik dalem yang berada di zona privat atau semi privat.

\section{Kelompok 2}

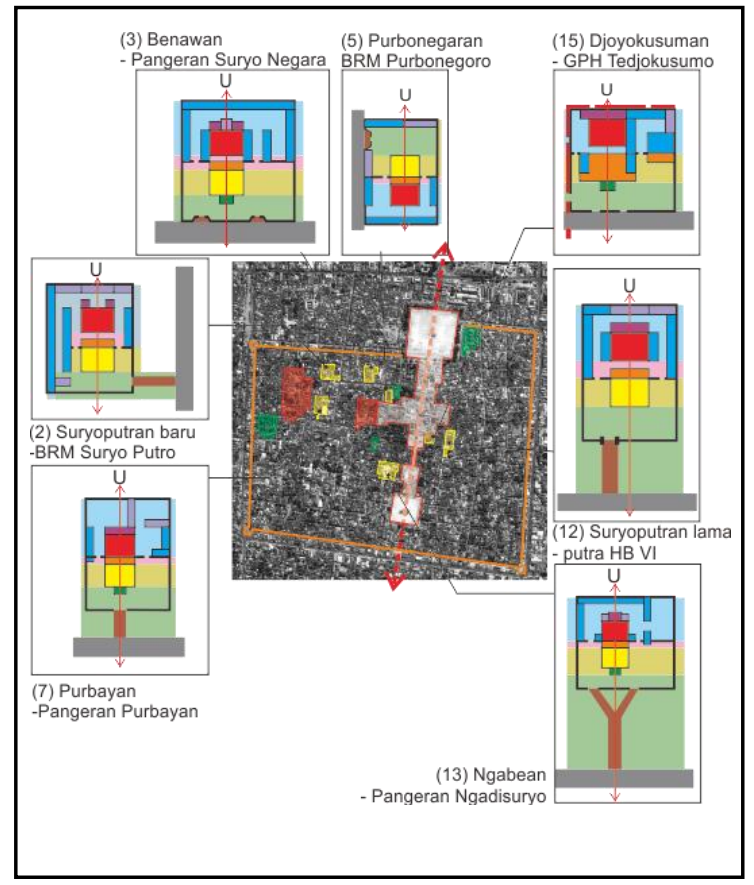

Gambar 5. Dalem kelompok 2

Sumber : Adianti, 2019

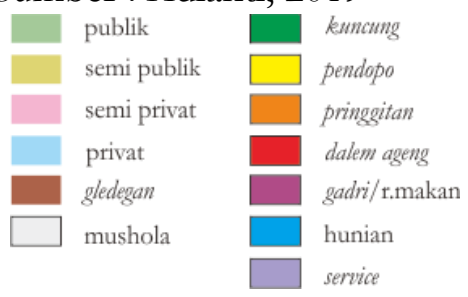

Kelompok ini memiliki jumlah dalem yang paling banyak, yaitu 7 buah. Dominan letak dalem berada di barat Kraton dan orientasi bangunan menghadap selatan. Hanya ada 1 dalem yang memiliki orientasi ke utara. Gledegan dimiliki hampir semua dalem, bahkan dengan posisi regol yang berhimpitan dengan jalan tetap berusaha membuat gledegan walapun hanya pendek. Hanya 1 dalem yang tidak memiliki gledegan dan tidak memiliki pendopo sebagai penerima tamu. Sebagai gantinya dibuat paviliun di sisi timur dalem ageng sebagai ruang penerima tamu. Hal ini dikarenakan lahan yang sempit karena posisi terhimpit oleh tembok cepuri disisi utara dan barat dalem serta jalan.

Tata ruang bangunanny sesuai prinsip rumah joglo, jika terdapat area privat (hunian) di zona publik, hunian tersebut diperuntukkan untuk abdi dalem yang bertugas di zona publik seperti abdi dalem patehan dan kandang kereta. Disetiap dalem pada kelompok ini memiliki gadri di belakang dalem ageng sebagai ruang berkumpul tapi yang bersifat privat. Tetapi semua dalem tidak memiliki mushola/langgar pada kompleks dalemnya.

Kelompok 3.

Dalem pada kelompok ini sebagai hunian kerabat raja diamana seseorang yang dianggap penting oleh raja

Pada kelompok ini mulai ditemukan orientasi bangunan menghadap utara dan tidak tidak adanya gledegan di kompleks dalem karena regol berhimpitan dengan jalan umum. Tata ruang masih megikuti prinsip rumah joglo, jika terjadi perletakan ruang yang seharusnya di ruang privat seperti pada dalem Condrokiranan dikarenakan ruang hunian tersebut mendukung kegaiatan di zona publik. Ruang service juga perletakannya disesuaikan dengan kegaiatan yang di wadahi, serta dimana kegiatan tersebut berlangsung. Pada dalem 
Kaneman ruang penyimpanan gamelan diletakkan didepan karena kegiatan yang menggunakan gamelan biasanya berlangsung di pendopo. Penempatan ini dikarenakan adanya pertimbangan akses

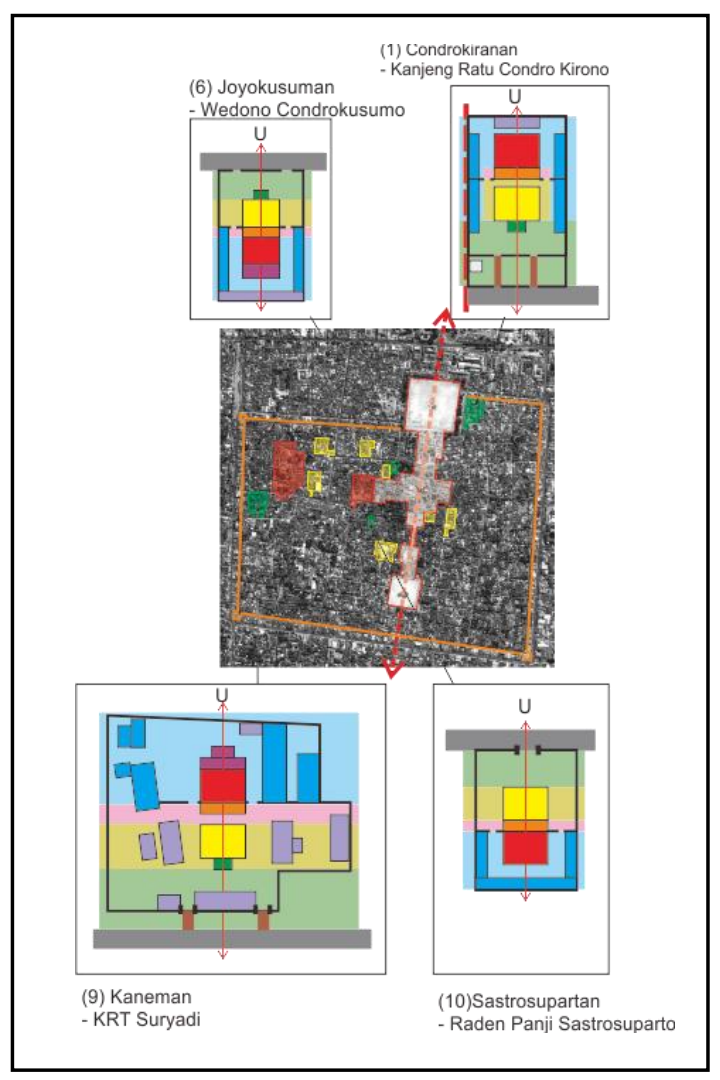

Gambar 6. Dalem kelompok 3

Sumber : Adianti, 2019

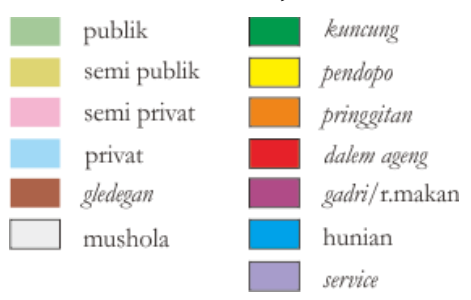

\section{KESIMPULAN DAN MASUKAN}

Tata Ruang dalem di dalam baluwarti Kraton Yogyakarta sebagian besar sesuai dengan prinsip rumah joglo pada rumah tradisonal jawa. Terutama pada dalem kelompok 1 dimana dalem tersebut digunakan oleh putra mahkota. Tetapi terjadi pergeseran pada tata ruang dalem, terutama pada arah orientasi yang tidak lagi menghadap ke Selatan, akan tetetapi menghadap ke Utara. Perubahan ini terjadi pada dalem kelompok 3, hal ini dikarenakan kaitan dengan raja tidak sedekat kelompok 1 dan 2 . Sebaran ruang walaupun ada ketidak sesuain dengan prinsip rumah joglo, akan tetapi ruangruang tersebut mendukung kegiatan sesuai zonannya. Ruang yang berada di halaman depan dikategorikan sebagai zona publik dan zona semi publik, sedangkan ruang yang berada dihalaman belakang dikategorikan zona semi privat dan zona privat.

Posisi dalem dominan berada di barat kraton dan yang hampir segaris dengan pusat Kraton (Kedhaton) adalah dalem Mangkubumen dan dalem Pakuningratan. Jika ada dalem yang berada di timur kraton, posisiya tidaklah segaris dengan Kedhaton.

\section{REFERENSI}

, Mosaic of Cultural Heritage Yogyakarta, Kementrian Pendidikan dan Kebudayaan Direktorat Jendral Kebudayaan Balai Pelestarian Cagar Budaya, 2004

Ikaputra, A Study on the 'Contextuallity ' of the Palace Environment Case Study: Noble Residences and its Magersari land right system in Yogyakarta, Indonesia. Tesis tidak diterbitkan. Department of Environment Engineering Faculty of Engineering Osaka University, 1993.

Kartono, Konsep Ruang Tradisonal Jawa dalam Konteks Budaya, Dimensi Interior p:124-136, Surabaya, 2005

Setyabudi,dkk, Tipologi dan Morfologi Arsitektur Rumah Jengki di kota Malang dan Lawang, Arsitektur e-Journal, 2012 
Sulistyawati, Nama dan Gelar di Keraton

Yogyakarta, Humaniora p:263-

275, 2004

Wibowo, Arsitektur Tradisional Daerah Istimewa Yogyakarta,

Departemen Pendidikan dan

Kebudayaan RI, Jakarta, 1998

Widyasari, Tata Ruang Rumah

Bangsawan Yogyakarta, Dimensi

Teknik Arsitektur p:122-132,

Surabaya, 2002

Yuniastuti, Perubahan Bentuk Bangunan

Dalem Mangkubumen

Yogyakarta, Lembaga Pelatihan

Jurnalistik (LPJJ), Yogyakarta, 2010

www.kratonjogja.id/tata-rakiting-

wewanunan, Tata Ruang dan

Bangunan Kawasan Inti Kraton

Yogyakarta, diakses 19 Juli 2019. 